水環境学会誌 Journal of Japan Society on Water Environment Vol.27, No.11, pp.685-691 (2004)

〈論 文-Original Paper〉

\title{
わが国の水環境中における人用・動物用医薬品の存在
}

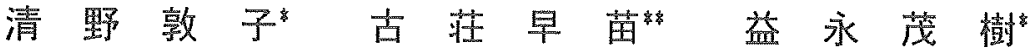

\section{Occurrence of Pharmaceuticals Used in Human and Veterinary Medicine in Aquatic Environments in Japan}

\section{Atsuko SEINO*, Sanae FURUSHO** and Shigeki MASUNAGA*}

* Graduate School of Environment and Information Sciences, Yokohama National University, 79-7 Tokiwadai, Hodogaya-ku, Yokohama-shi, Kanagawa, Japan

** JASCO INTERNATIONAL CO., LTD., 11-10 Myojin-cho 1-chome, Hachioji, Tokyo, Japan

\begin{abstract}
In recent years, pharmaceuticals in the aquatic environment have attracted much attention in Europe and North America due to their potential to increase antibiotic resistance in microorganisms and their ecological effects on aquatic organisms. Little information, however, has been reported from Japan. In this study, we report on the levels of human and veterinary pharmaceuticals in aquatic environments in Japan. A liquid chromatograph coupled with a tandem mass spectrometer was used to detect these compounds. The results showed that certain pharmaceuticals were detected at $n g \cdot l^{-1}$ level. The concentrations of human pharmaceuticals in rivers located in urban areas were higher than those in suburban areas, while pharmaceuticals mainly used for veterinary medicine were found of higher concentration in suburban areas. Human pharmaceuticals were also detected the sewage treatment plant effluent. In agricultural wastewater, some antibiotics for veterinary use were detected at high concentrations of up to $\mu \mathrm{g} \cdot l^{-1}$ level, which indicated possible ecological effects in some limited areas.
\end{abstract}

Key words :pharmaceuticals, aquatic environment, municipal river, agricultural drainage

\section{1.はじめに}

医蒋品は人の医療や畜産分野においてに大垩に使用さ れている。近年, 鲑境中の微量化学物質に対する研究の発 展之其に，環境中における医薬品の存在や水生生物入の影 響について関心が高まっている 持つ物質が多く，年間を通じて使用されているものもある。 医薬品は生体内で代謝された後尿中に排泄されるものが 多く，下水道または浄化槽を通して下水処理場や浄化槽を 経て水環境中に放出される。欧米では河川水，湖水，下水 処理場処理水, ゴミ処理場浸出水, 病院排水などからさま ざまな医薬品が検出されている゙〜7ため，医薬品の製造規 制に環境りスク評洒を組み込むことが提案されている ${ }^{8,9)}$ このように世界的に環境中の医荣品漕度や水生生物への 影響評価についての研究が必要となっているが，わが国で は環境中から医楽品を検出した報告はほとんどないが，わ が国の人用と動物用医薬品の生産肘売高は、それぞれ約 6500 億円と ${ }^{10)}$ ，51億円 ${ }^{11)}$ ということから医蔝品が大量に消 費されていることがうかがえる。人用医楽品のうち使用量 の多いものは, 血圧降下剂, 消化性謴場用剂, 血管拡張剂, 解熱鎮痛消炎剂，抗菌剂，精神神経用剂などであり ${ }^{10)}$ ，畜 産において使用量の多いものは抗生物質、ホルモン製剂で

* 横浜国立大学環境情報研究院・学府 $\bar{\top} 240-8501$ 横浜市保土ケ谷区常盤台79-7

**ジャスコインタナショナル株式会社Ｔ192-0046 東京都八王子市明神町1-11-10
ある。抗生物質の使用量は畜産における使用量が人の使用 量をはるかに上回る ${ }^{12)}$ 。これら使用量の多い医楽品は諸外 国においてもしばしば分析の対象とされている。

日本の河川は欧米と比較して短く、流量・流域面積も小 さい。また、医薬品の使用と廃裹方法や下水道システムは、 国によって若干の違いがあり、報告されている諸外国にお ける環境中の医薬品䟴度はわが国には当てはまらないこ とが予想される。本研究では、わが国の環境中における医 薬品の存在状況在把握するために、環境水試料における医 蒋品の分析方法を確立し, 神奈川県と東京都の河川水・下 水処理場放流水・農業排水中の医楽品を分析した。また、 下水処理場放流水が流量のほと九どを占める都市河川之、 農業・畜産業が盛んな農業地帯を流れる河川を比較するこ とにより、検出される医薬品の種類の違いを論じた。

\section{2. 方法}

2.1 サンプリング

下水処理場放流水が流量のほとんどを占める都市河川 として多摩川・鶴見川、農業・音産業が盛えな農業地带を 流れる河川として金目川を本研究の対象に選んだ（Fig. 1-a）。多摩川は幹川流路延長 $138 \mathrm{~km}$ 、流域面積 $1240 \mathrm{~km}^{2}$ 、 流域人口 340 万人の一級河川 ${ }^{13)}$ 、鶴見川は幹川流路延長 43 
$\mathrm{km}$ 、流域面積 $253 \mathrm{~km}^{2}$ 、流域人口170万人の一級河川である 14)（Fig. 1-b）。これらの河川流域の下水道普及率は焼く90 $\%$ であり，流域に多数の下水好理場が存在し，河川流量に おける下水処理場放流水の上める割合が高い。金目川は総 路延長 $89 \mathrm{~km}$ 、流域面積 $389 \mathrm{~km}^{2}$ の二級河川であり、鈴川・ 渋田川・金目川の3つの大きな支流から構成される15（Fig. 1-c）。金目川水系には下水処理場はそれぞれ鈴川に伊勢 原終末処理場，金目川に秦野市浄水管理センターの2簀所 しかなく下水道普及率は約 $70 \%$ で処理人口は35万人であ る。下水道が普及していない地域の家庭や事業所には浄化 槽が設置さ㧈ている。また，鈴川の中流域には農業地域が 広がり，各鹿家には浄化槽が設置され，直接河川へ上処理 水が放流されている地域が多い。

多摩川，鶴見川，金目川でそれぞれ下水処理場放流水上 河川水、金目川で農業排水路から採水した。採水日3日前 に雨が降らないことを条件に，多摩川では2003年12月22 日，鶴見川は2003年6月20日，金目川は2003年12月19日， 2004年2月18日にサンプリングを行った。

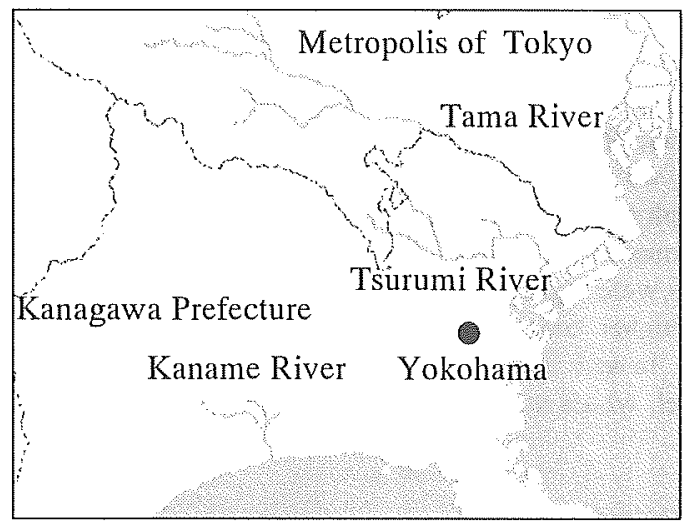

Fig. 1-a Location of Tama River and Tsurumi River in Kanagawa and Tokyo

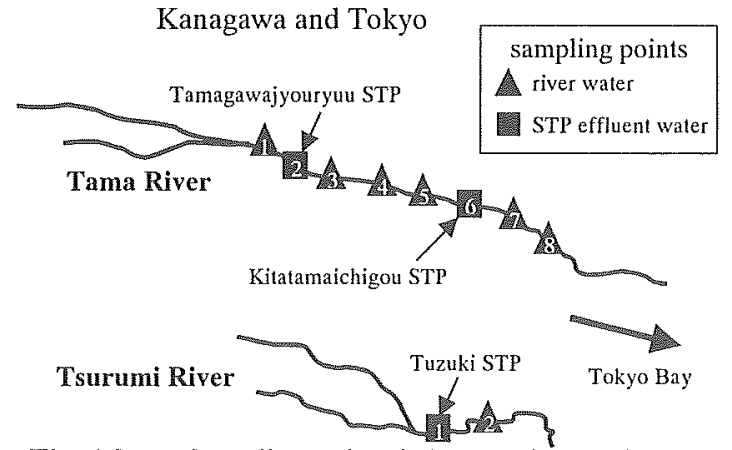

Fig. 1-b Sampling points in Tama River and Tsurumi River.STP: sewage treatment plant

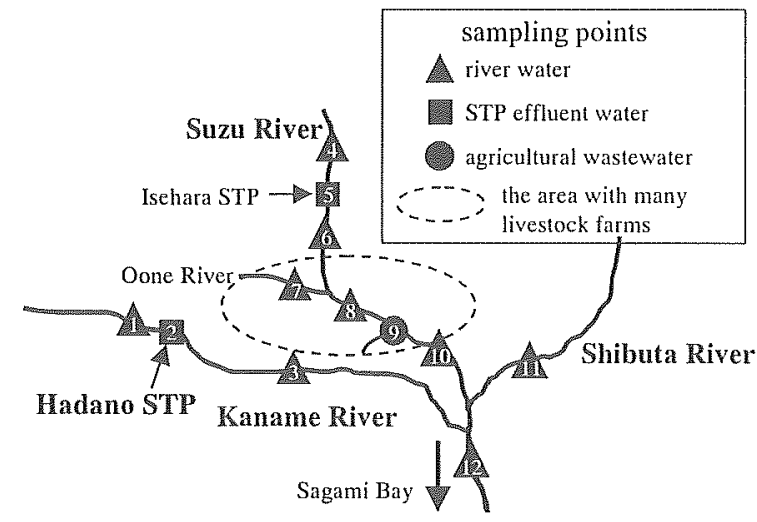

Fig. 1-c Sampling points in Kaname River

\section{2 対象物質}

標準物質として、和光純莧 (株)加抗生物質 (tetracycline hydrochloride, oxytetracycline hydrochloride, chlortetracycline hydrochloride），合成抗菌剂 (sulfadimethoxine, sulfamethoxazole)，抗生物質（tylosin tartarate）を入手し, SIGMA Ardrich Japanより $\beta$ ブロッカー (propranorol hydrochloride)，抗てんかん薬 (carbamazepine) を入手した。去た，内部標準物質としてCDN Isotopeより carbamazepine d-10t, Cambridge Isotope Laboratories Inc.よ

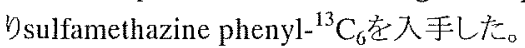

2.3 分析方法

(1) サンプル採取

水試料はステンレス製のバケツで採取し，褔色瓶に入れ 冷蔵で研究室まで持ち帰った。 $4^{\circ} \mathrm{C}$ で保存し，48時間以内 に抽出処理を行った。

(2) 固相抽出

水試料洒酢酸でpH 5 に調整し，EDTAを試料 1 lに対し約 $200 \mathrm{mg}$ 添加した ${ }^{16)}$ 。振とう後, 試料 $100 \mathrm{ml}$ に対し内部標準 物を10ng添加した。固相抽出カートリッジはSHODEX EDS-1 (昭和電工) を用いた。カートリッジはメタノール, 純水それぞれ各 $10 \mathrm{~m} /$ 用いてコンディショニングし, 流速 $10 \mathrm{~m} / \cdot \mathrm{min}^{-1}$ で試料 $200 \mathrm{~m} l$ を通水した。通水後純水 $10 \mathrm{~m} /$ で カートリッジ内を洗浄し, 加圧によりカートリッジ内の水 分を除去後, $1000 \mathrm{rpm}$ で5分間遠心分離を行いカートリッ 汭内の水分をできるだけ除去した。カートリッジにメ夕， 一ル $5 \mathrm{ml}$ づつ2回に分けて注入し，自然滴下で溶出液を収 集した。さらに窒素パージで乾固した後メタノール $1 \mathrm{ml}$ に丽溶解したものを抽出夜とした。

(3) 機器分析

HPLCシステムはAlliance 2695（Waters）を用いた。カラ ムはZorbax Ecripse C18（Agilent）を用い，移動相はA;アセ トニトリル・酰酸 $0.1 \%$ 溶液とB; 水・酰酸 $0.1 \%$ 溶液を用い て流量 $0.2 \mathrm{~m} / \cdot \mathrm{min}^{-1}$ でグラジエント分析を行った。グラジ エント条件はTable 1に示した。検出器は夕ンデム質量分 析機Quatro Ultima（Micromass）を用い，ポジティブイオ ンモードで測定した。それぞれの化合物の親イオンと娘イ オン, MS/MS最適条件はTable 2にまとめた。カルバマゼ ピン, プロプラノロール, スルファジメトキシン, スルフ アメトキサゾール, タイロシン, カルバマゼピン・サルフ ア剂の内部標準物質はそれぞれ $10 \mu \mathrm{g} \cdot l^{-1}$ の濃度になるよ うに添加し, テトラサイクリン, オキシテトラサイクリン, クロルテトラサイクリンは50 $\mu \mathrm{g} \cdot l^{-1}$ になるように添加し た河川水試料から得られたクロマトグラムをFig.2に示し た。テラサイクリンとクロルテトラサイクリンは目的物 質のピークの前に小さいピークが認められ、これは標準物 質にも見られた。テトラサイクリン系抗生物質はエピ異性 体が存在することが知られており ${ }^{17)}$ ，このピークはエピ異 性体ということが推測された。今回は本ピークのみをテト ラサイクリンとクロルテトラサイクリンとして計算した。

Table 1 High performance liquid chromatography with binary gradient program for simultaneous analysis of target compounds

\begin{tabular}{crrrrrrr}
\hline time $(\min )$ & 0 & 5 & 7 & 7.01 & 13 & 13.01 & 24 \\
\hline$\% \mathrm{~A}$ & 10 & 80 & 90 & 100 & 100 & 10 & 10 \\
\hline
\end{tabular}


Table 2 Monitor ion and optimized parameters for each target compound

\begin{tabular}{cccccc}
\hline & $\begin{array}{c}\text { parent ion } \\
(\mathrm{m} / \mathrm{z})\end{array}$ & $\begin{array}{c}\text { daughter } \\
\text { ion }(\mathrm{m} / \mathrm{z})\end{array}$ & $\begin{array}{c}\text { capillary } \\
\text { voltage }(\mathrm{kV})\end{array}$ & $\begin{array}{c}\text { cone } \\
\text { energy }(\mathrm{V})\end{array}$ & $\begin{array}{c}\text { collision } \\
\text { energy }(\mathrm{eV})\end{array}$ \\
\hline carbamazepine & 237.0 & 193.9 & 3.2 & 65 & 18 \\
propranolol & 260.0 & 116.0 & 3.2 & 40 & 18 \\
sulfadimethoxine & 311.0 & 155.9 & 3.2 & 80 & 20 \\
sulfamethoxazol & 253.9 & 155.8 & 3.2 & 60 & 15 \\
tylosin & 916.7 & 174.0 & 3.2 & 80 & 40 \\
tetracycline & 445.1 & 410.0 & 3.2 & 65 & 18 \\
oxytetracycline & 461.0 & 426.0 & 3.2 & 70 & 18 \\
chlortetracycline & 479.0 & 444.0 & 3.2 & 65 & 21 \\
carbamazepine d-10 & 247.0 & 204.0 & 3.2 & 65 & 18 \\
sulfamethazine $13 \mathrm{C} 8$ & 285.0 & 203.9 & 3.2 & 60 & 15 \\
\hline
\end{tabular}

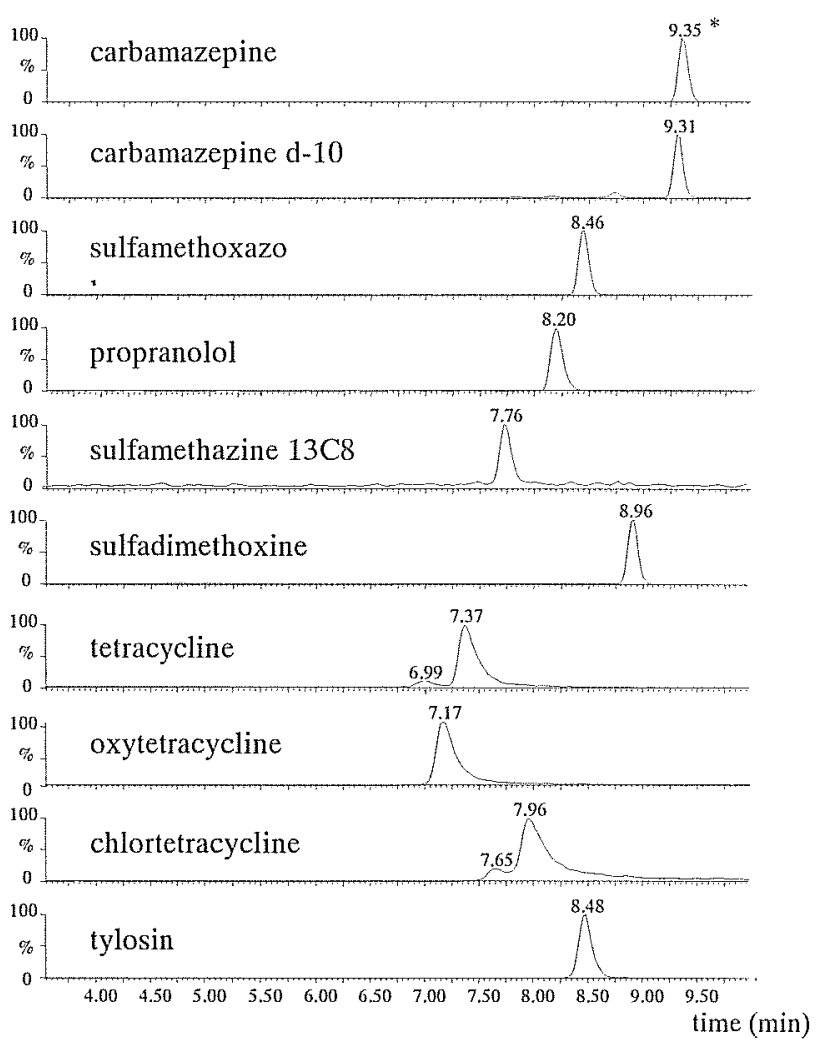

Fig. 2 Chromatograms of target compounds by the LC/MS/MS analysis *;retention time (min)

\section{3.結果と考察}

\section{1 回収率}

絉水・河川水・下水処理場放流水について、試料 $200 \mathrm{ml}$ あたりテトラサイクリン系抗生物質は50 ng, その他の物 質は10ng添加して、添加回収試䝠を行った。当初は内部 標準物質が入手できない物質については絶対検量線法で 計算していたが, 試料中のマトリクスによってイオン化が 影響され，標準物質溶液とサンプルとの検量線の傾きが変 化するため回取率が不安定だった（Fig. 3）。試料による マトリクスなどの影響を考虑するためには，試料ごとに检 量線を求めて浱度を計算することが必要亡考え，内部標準 物質がない物質については䐼準添加法で計算することに した。試料抽出液に濃度の異なる標準物質溶液をそれぞれ

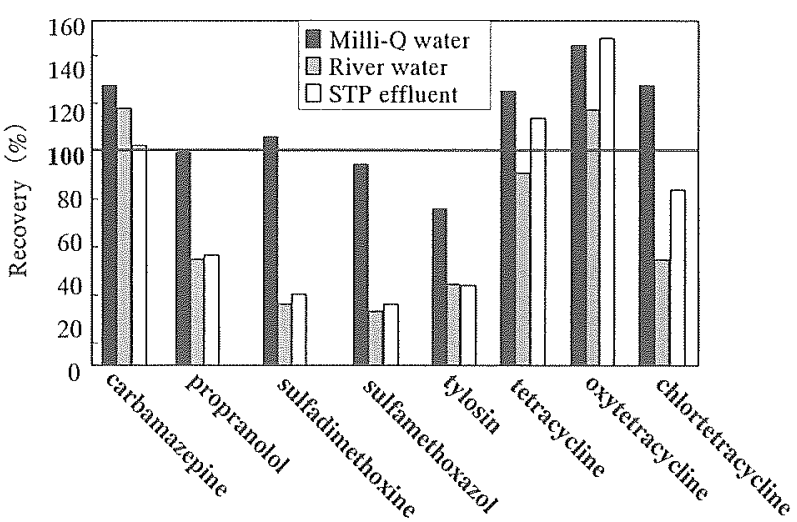

Fig. 3 The recovery rates of pharmaceuticals calculated by absolute calibration curve. The recoveries of pharmaceuticals in ultra pure water were good, but these in river water and STP effluent water were low

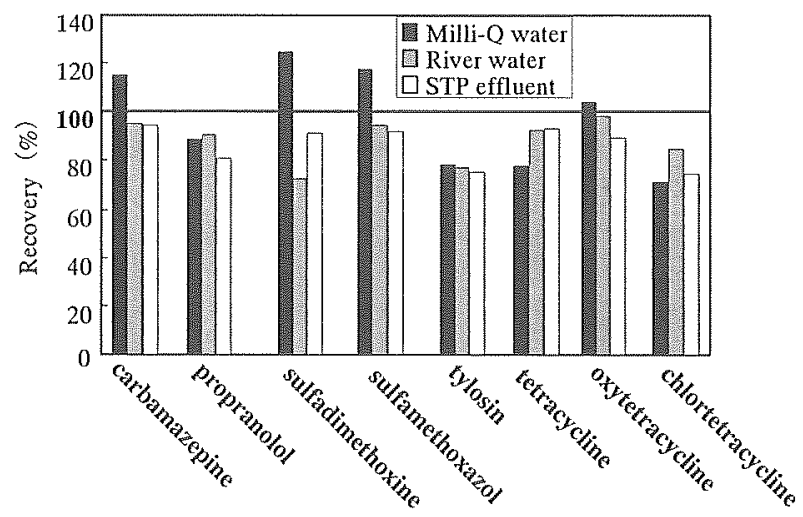

Fig. 4 The recovery rates of pharmaceuticals calculated by the internal standard calibration and the standard additional method

添加し, 添加濃度とその濃度におけるピーク面穦值から㭘 量線を作成して濃度を算出した。抽出液 $200 \mu$ と標华物質 䡋度 $0 \mu \mathrm{g} \cdot l^{-1}, 0.8 \mu \mathrm{g} \cdot l^{-1}, 4 \mu \mathrm{g} \cdot l^{-1}, 20 \mu \mathrm{g} \cdot l^{-1}$ のメ夕ノール 溶液をそれぞれ $200 \mu l$ 混合し，1試料あたり4濃度の抽出液 を作成した。テトラサイクリン,オキシテトラサイクリン, クロルテトラサイクリンは感度が覀いため標準添加荟度 汥 $4 \mu \mathrm{g} \cdot l^{-1}, 20 \mu \mathrm{g} \cdot l^{-1}, 100 \mu \mathrm{g} \cdot l^{-1}$ とした。内部標準物質が 入手できるカルバマゼピン・サルファ剤については，内部 標準法を用いて日的物質を定量した。標準添加法を用いる 之, 純水, 河川水, 下水処理場放流水に上る回収率の差が 見られなくなったため（Fig。4），内部標準法で計算でき ない物質については標準添加法を用いることとした。この 方法で测定した純水，河川水，下水処理場放流水に㧍ける 添加回収試験の結果と定量限界值（標準物質のクロマトグ ラムにおいてS / N = 10で計算した值）をTable 3に示した。

\section{2 分析結果}

(1) 都市河川

多摩川・鶴見川のサンプリング地点の詳細をTable 4 に 示し，分析結果をFig. 5に示した。多摩川・鶴見川ともに カルバマゼピン, プロプラノロール, およびスルファメト キサゾールは全てのサンプルからng $l^{-1}$ オーダーで検出 された。カルバマゼピン、プロプラノロール，スルファジ メトキシン，およびスルファメトキサゾールは，下水処理 場放流水中の濃度がその下水処理場前後の河川水中の濃 
Table 3 Average recovery, RSD (relative standard deviation) and LOQ (limit of quantification) of the analytical method used in this study

\begin{tabular}{|c|c|c|c|c|c|c|c|c|c|}
\hline & \multicolumn{2}{|c|}{ ultra pure water } & \multicolumn{2}{|c|}{ river water } & \multicolumn{2}{|c|}{ STP effluent water } & \multicolumn{2}{|c|}{ agricultural wastewater } & \multirow{2}{*}{$\begin{array}{c}\text { LOQ }(\mathrm{ng} / \mathrm{L}) \\
\mathrm{S} / \mathrm{N}=10\end{array}$} \\
\hline & recovery $(\%)$ & RSD & recovery $(\%)$ & RSD & recovery $(\%)$ & RSD & recovery $(\%)$ & RSD & \\
\hline carbamazepine & 115.0 & 0.0 & 86.4 & 3.2 & 65.0 & 7.7 & 97.4 & 6.8 & 0.03 \\
\hline propranolol & 88.9 & 0.1 & 80.9 & 1.7 & 111.6 & 3.0 & 88.5 & 6.4 & 0.2 \\
\hline sulfadimethoxine & 124.6 & 3.3 & 54.3 & 4.0 & 85.0 & 7.1 & 55.6 & 14.0 & 0.03 \\
\hline sulfamethox azol & 117.8 & 3.6 & 91.3 & 8.6 & 68.6 & 25.0 & 91.5 & 16.1 & 0.2 \\
\hline tylosin & 78.1 & 5.3 & 57.8 & 2.9 & 92.4 & 6.5 & 69.6 & 5.5 & 0.01 \\
\hline tetracycline & 77.5 & 2.7 & 104.0 & 15.3 & 154.0 & 10.1 & 92.1 & 8.8 & 3.4 \\
\hline oxytetracycline & 104.0 & 2.7 & 96.0 & 14.1 & 129.3 & 11.9 & 130.2 & 19.6 & 1.5 \\
\hline chlortetracycline & 71.5 & 10.9 & 65.3 & 10.0 & 108.3 & 11.7 & 70.3 & 8.7 & 7.9 \\
\hline
\end{tabular}

度よりも高い傾向が見ら扎た。また，多摩川上流下水処理 場より上流の河川水からはカルバマゼピン $\left(1.5 \mathrm{ng} \cdot l^{-1}\right)$ とプロプラノロール $\left(0.1 \mathrm{ng} \cdot l^{-1}\right)$ が検出されたのみだっ たが,多摩川上流下水処理場の下流(多摩大橋TM3) では、 カルバマゼピン (15.8 $\left.\mathrm{ng} \cdot l^{-1}\right)$, プロプラノロール (3.2 ng $\left.\cdot l^{-1}\right)$, スルファジメトキシン $\left(0.3 \mathrm{ng} \cdot l^{-1}\right)$, スルファメ トキサゾール $\left(5.9 \mathrm{ng} \cdot l^{-1}\right)$ が検出された。多摩川上流下 水処理場の上流には下水処理場がないことから,これらの 医楽品の河川への主な排出源は下水処理瑒放流水と考光 られた。カルバマゼピンとプロプラノロールのみ下水処理 場の上流から検出されたが、下水道が普及されていない上 流地域の浄化槽から排出された可能性が考光られた。平成 14年莧事工業生産動態統計年報から計算したカルバマゼ

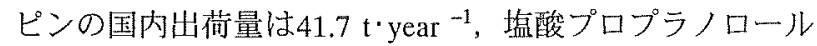
$1.26 \mathrm{t}^{\cdot} \mathrm{year}^{-1}$, スルファジメトキシン $1.19 \mathrm{t} \cdot \mathrm{year}^{-1}$, スルフ アメトキサゾール4.28 t'year ${ }^{-1}$ である10)。スルファメトキ サゾールがスルファジメトキシンよりも高濃度で検出さ れているのは生産量の違いであると推测できる。

テトラサイクリン, クロルテトラサイクリンは全てのサ ンプルから検出されなかった。タイロシンは動物用医薬品 にの夕認可されている抗生物質だが, 河川水で4地点, 下 水処理場で2地点から検出され, 放流水と河川水の濃度に 差がなかった。横浜市は畜産農家からの排水も全て下水道 八放流していることや，北多摩1号下水処理場の処理区内 にも畜産農家が存在していることから夕イロシンが下水 道へ流入し，下水処理場放流水に存在する可能性がある。 オキシテトラサイクリンは動物用としての使用量が人の 使用量を上回っており，都筑下水処理場上北多摩1号下水 処理場の放流水からの検出奶畜産由来の可能性が考えら れた。

(2) 金目川

金目川のサンプルとサンプリング地点の詳細をTable 5 に，濃度結果をFig. 6に示した。2003年12月と2004年2月の 2回採水を行ったが，ほぼ同様の傾向であった。下水処理 場の上流と下流のカルバマゼピンとプロプラノロールの 濃度は下水処理場を挟九で下流の濃度が高くなり，それぞ れの下水処理場放流水の濃度河川水と比較して高く, 多 摩川と鶴見川と同様の結果が得られた。しかし，下水処理 場放流水が流入していない地点（K7，K11）においても人 用医楽品が検出された。金目川流域の下水道が普及してい ない地域の家庭では浄化槽で処理排水を放流しているた め，金目川では下水処理場以外にも各家庭の浄化槽からの 排出源があるここが示唆さ扎た。
Table 4 Samples taken from Tama River and Tsurumi River.

\begin{tabular}{cll}
\hline $\begin{array}{c}\text { name of } \\
\text { river }\end{array}$ & $\begin{array}{c}\text { sample } \\
\text { ID }\end{array}$ & \multicolumn{1}{c}{ sample property } \\
\hline Tama River & TM1 river water & upper stream of Tamagawajyouryu STP \\
& TM2 STP effluent water & Tamagawajyouryu STP \\
TM3 river water & Tamaoo Bridge \\
TM4 river water & Hino Bridge \\
TM5 river water & Sekido Bridge \\
TM6 STP effluent water & Kitatama1gou STP \\
TM7 river water & Hara Biridge \\
TM8 river water & Maruko Bridge \\
Turumi Rive & TR1 STP effluent water & Tuzuki STP \\
TR2 river water & Shinkawamukou Bridge \\
\hline
\end{tabular}
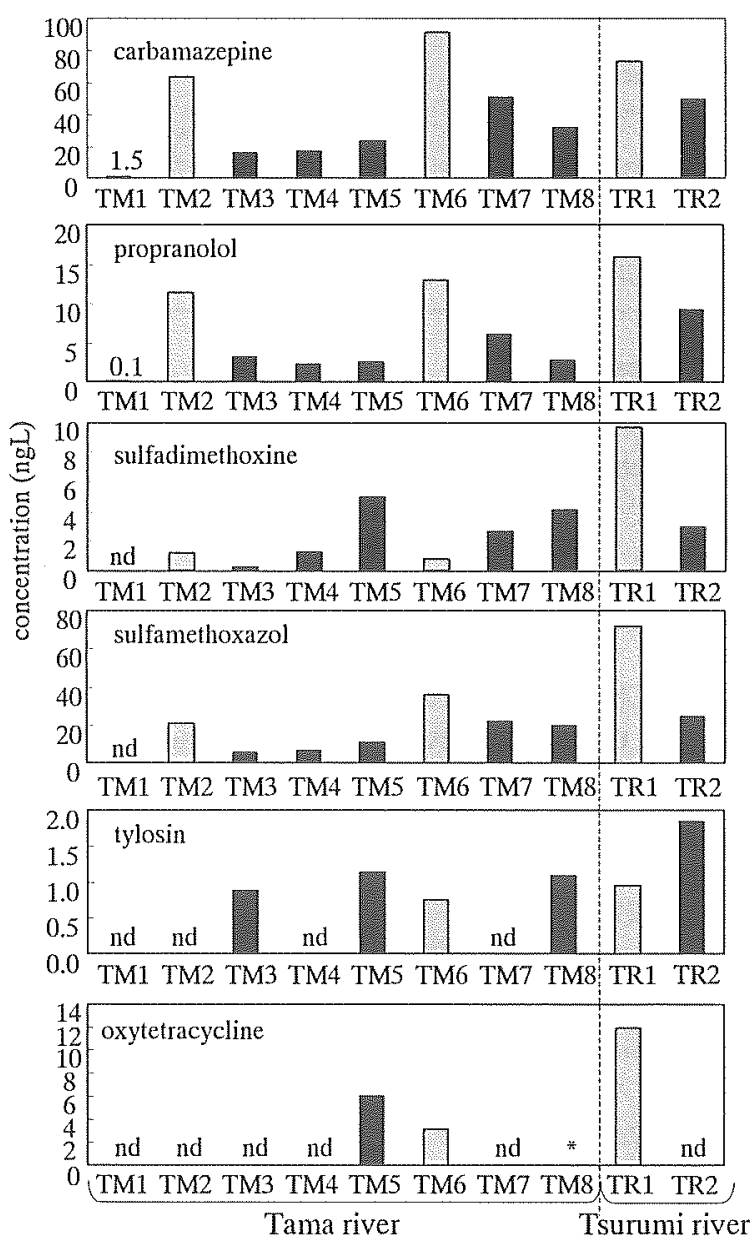

Fig. 5 Concentrations of pharmaceuticals in river water and STP effluent water in Tama River and Tsurumi River.

Viver water nd;not detected $\square$ STP effluent water *;trace $(<\mathrm{LOQ})$ 
スルファジメトキシンとスルファメトキサゾールは，河 川水や農業排水が多く含まれると考觉られる地点 (K7, K8, K9，K10）において下水処理場放流水よりも高濃度で検出 され，その濃度は多摩川・鶴見川と比較すると2 5倍高い 濃度レベルであった。鈴川に合流する大根川周辺は低湿地 苗になっており流量は少ないが淀みやすい。大根川と鈴川 流域にはたくさんの羑豚農家が存在し，榎田排水路などの 農業排水路に農家からの排水が集めら扟鈴川に流れ込ん でいることから，大根川大畑橋（K7）と榎田排水路（K9） は音産排水が多く含まれることが推測される。また、これ らの水が流入する鈴川は畜産排水の寄与を大きく受ける 之考えられる。合成抗菌剂や抗生物質は畜産分野で大量に 使用され，特にスルファメトキサゾール，タイロシン，才 キシテトラサイクリン, クロルテトラサイクリンの使用が 多い。そのため, 金目川の河川水から検出されたサルファ 剂や抗生物質は畜産由来の可能性が高い。2004年2月のサ ンプルにおいて，農業排水路である榎田排水路（K9）で スルファジメトキシン, スルファメトキサゾール，タイロ シン, テトラサイクリン, オキシテトラサイクリン, クロ ルテトラサイクリンが検出され，章産排水に含まれと河川 へと流れ込む抗生物質や合成抗囷剤の存在が明らかにな つた。

渋田川（K11）のサンプルからはスルファジメトキシン とクロルテトラサイクリンが最も高濃度に㭘出された。橴 田川流域には下水処理場は無いが, 畜産屡家は点在してい

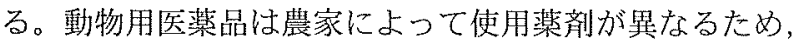
渋田川流域の農家でスルファジメトキシンとクロルテト ラサイクリンを使用していることが推测でさる。各農家の 浄化槽で音産排水は約2 4日おきに放流されている。今回 のサンプルはすべてグラブサンプルであり，採水時に採水 地点付近の農家が排水を放流していた場合，一時的に抗生 物質の濃度が上昇す为ことが考えられた。

金目川下流（K12）は金目川，鈴川，啮田川が合流し相 模湾へ流入する前の地点であるが，2回の採水時期におい て検出された医馥品数は8物質中7物質であり他の地点と 比較すると最も多かった。下流域は医薬品の検出頻度が高 くなることから医楽品が河川水中に残留する傾向が示さ れた。

\section{3 海外の報告值との比較}

本研究の対象物質の下水処理場放流水および河川水中 における検出濃度・検出頻度について、本研究で得られた デー夕を海外で報告されているデー夕と比較した（Table 6, Table 7)。下水処理場放流水において，カルバマゼピ ンとプロプラノロールは欧米で検出された㴽度が約10倍 高い濃度レベルであった。カルバマゼピンの1995年ドイツ における使用量は80 t'year ${ }^{-1}$ であり ${ }^{4)}$, 日本の出荷量41.7 t - year ${ }^{-1}$ と比較すると約 2 倍の使用量と推算でさる。これら の物質の下水処理場放流水中濃度が高いことは, 使用量の 違いよりも下水処理場の処理能力の違いが関係している と推測できる。また，河川水においても本研究の人用医薬 品の検出漂度と比較すると欧米の検出濃度が高い傾向が 見られたが，デー夕の数が十分でない上，医莧品の使用状 沿や採水地点の詳細情報, 河川形態などが各国異なるため, 単純な比較は出来ない。
Table 5 Samples taken from Kaname River

\begin{tabular}{|c|c|c|c|}
\hline $\begin{array}{l}\text { name of } \\
\text { river }\end{array}$ & $\begin{array}{l}\text { sample } \\
\text { ID }\end{array}$ & sample properiy & sampling point \\
\hline Kaname river & K1 & river water & upper stream of Hadano STP \\
\hline Kaname river & $\mathrm{K} 2$ & STP effluent water & Hadano STP \\
\hline Kaname river & K3 & river water & $\begin{array}{l}\text { Tuchiya bridge (down stream } \\
\text { of Hadano STP) }\end{array}$ \\
\hline Sizu river & K4 & river water & upper stream of Isehara STP \\
\hline Sizu river & K5 & river water & Isehara STP \\
\hline Sizu river & K6 & river water & down stream of Isehara STP \\
\hline Oone river & K7 & $\begin{array}{l}\text { river water (major } \\
\text { portion of agricultural } \\
\text { wastewater) }\end{array}$ & Oohata Bridge \\
\hline Suzu river & K8 & river water & Miyashita Bridge \\
\hline Suzu river & K9 & agricultural wastewater & Enokida drainage \\
\hline Suzu river & $\mathrm{K} 10$ & river water & Okazakioo Bridge \\
\hline Shibuta river & K11 & river water & Shinoonawa Brigdge \\
\hline Kaname river & $\mathrm{K} 12$ & river water & Komaoo Bridge \\
\hline
\end{tabular}
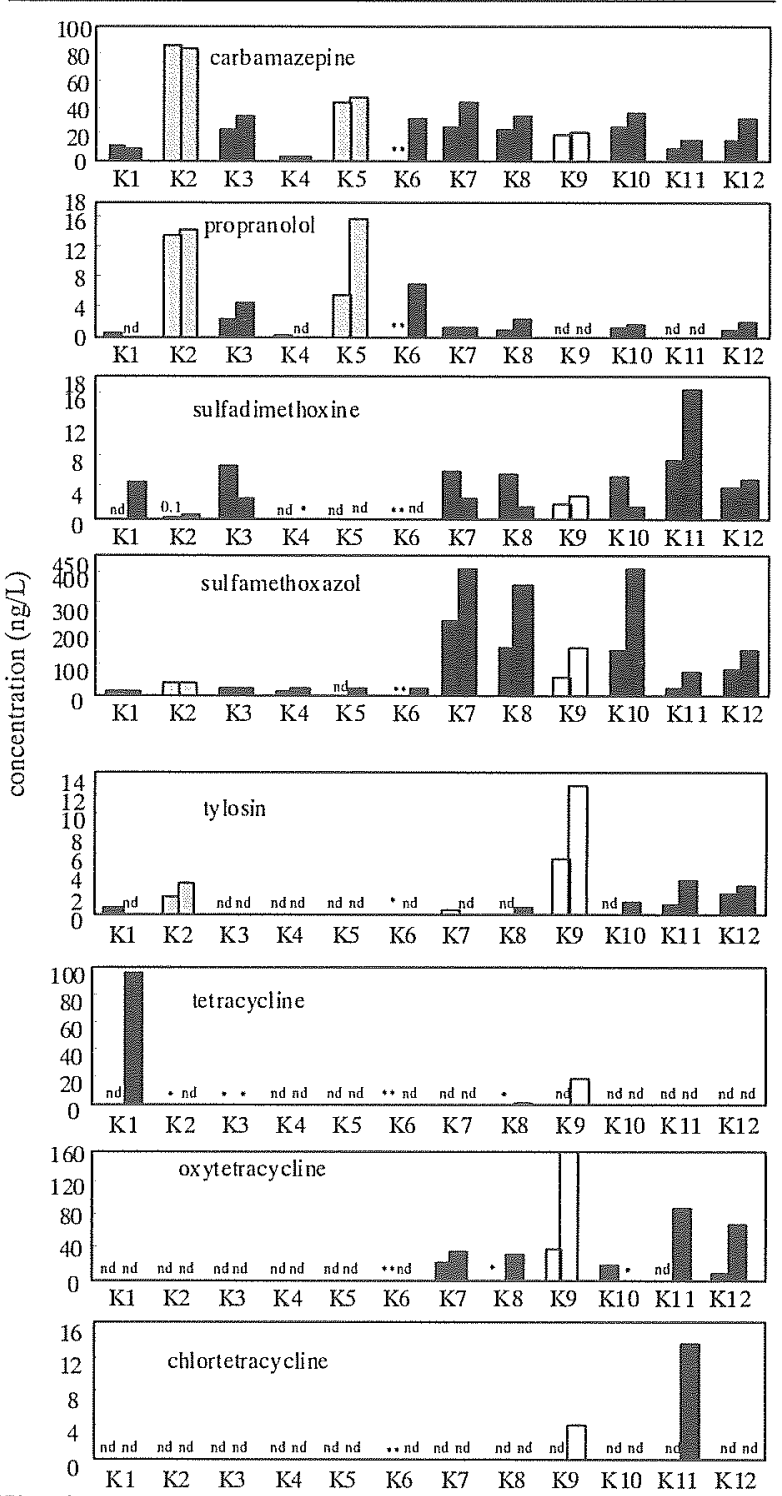

Fig. 6 Concentrations of pharmaceuticals in river water agricultural wastewater and STP effluent in Kaname River nd;not detected *; trace (<LOQ) **;not sampled river water $\square$ STP effluent $\square$ agricultural drainage 
Table 6 Concentrations of target compounds in STP effluent reported from western countries and this study nd;not detected

\begin{tabular}{|c|c|c|c|c|c|c|c|c|c|c|c|c|c|c|c|c|c|c|c|c|c|c|c|}
\hline & \multicolumn{2}{|c|}{ Japan (this study) } & \multicolumn{3}{|c|}{ Gemany } & \multicolumn{3}{|c|}{ Sweden } & \multicolumn{3}{|c|}{ France } & \multicolumn{3}{|c|}{ Greece } & \multicolumn{3}{|c|}{ Hary } & \multicolumn{3}{|c|}{ U.S.A. } & \multicolumn{3}{|c|}{ Canada } \\
\hline & $\begin{array}{l}\text { conc. } \\
\text { mill-max }\end{array}$ & $\begin{array}{c}\text { No, of } \\
\text { detection }\end{array}$ & $\begin{array}{l}\text { conc. } \\
\text { min-mix } \\
\text { or } \max \end{array}$ & $\begin{array}{l}\text { No. of } \\
\text { detection }\end{array}$ & ref. & conc. & $\begin{array}{l}\text { No. of } \\
\text { detection }\end{array}$ & ref. & $\begin{array}{l}\text { conc. } \\
\text { mint-max }\end{array}$ & $\begin{array}{c}\text { No. of } \\
\text { detection }\end{array}$ & ref. & conc. & $\begin{array}{l}\text { No. of } \\
\text { delection }\end{array}$ & ref. & 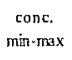 & $\begin{array}{l}\text { No. of } \\
\text { detection }\end{array}$ & ref. & $\begin{array}{l}\text { conc. } \\
\text { min-triax }\end{array}$ & $\begin{array}{c}\text { No. of } \\
\text { detection }\end{array}$ & ref. & $\begin{array}{l}\text { conc. } \\
\text { median }\end{array}$ & $\begin{array}{l}\text { No. of } \\
\text { detcetion }\end{array}$ & ref. \\
\hline carbamatrpine & $43.01-91.5$ & $7 / 7$ & 6300 & $30 / 30$ & (4) & 870 & $1 / 1$ & (19) $!$ & $980-120103$ & $2 / 2$ & (19) & 1030 & $1 / 1$ & (19) & $3(0)-500$ & $3 / 3$ & (19) & & & & 740 & $18 / 18$ & (21) \\
\hline propranolol & $5.4-16.0$ & $m$ & $<25-290$ & $28 / 29$ & (4) & 10 & $1 / 1$ & (19) & $10-40$ & $2 / 2$ & (14) & 10 & $1 / 1$ & (19) & 10.50 & $3 / 3$ & (19) & $26-1900$ & $34 / 34$ & (20) & & & \\
\hline sulfad inethoxine & $<0.03-9.7$ & $5 / 7$ & & & & & & & & & & & & & & & & & & & & & \\
\hline sulfarme thoxazon? & $<0.2 .71 .4$ & $6 / 7$ & 6506 & $10 / 10$ & (18) & 20 & $1 / 1$ & (19) & 70,90 & $2 / 2$ & (19) & 90 & $1 / 1$ & (19) ? & $\mathrm{nd}-30$ & $2 / 3$ & (19) & & & & & & \\
\hline tylosim & $<0.01-3.1$ & $4 / 7$ & & & & & & & & & & & & & & & & & & & & & \\
\hline tetracyclint & $<3.4$ & $0 / 7$ & $<50$ & 0.5 & (18) & & & & & & & & & & & & & & & & & & \\
\hline oxyletracycline & $<1.5-12$ & $2 / 7$ & 50 & $0 / 5$ & (18) & & & & & & & & & & & & & & & & & & \\
\hline chlostetracycline & $<7.9$ & $0 / 7$ & $<0$ & $0 / 5$ & (iB) 1 & & & & & & & & & & & & & & & & & & \\
\hline
\end{tabular}

Table 7 Concentrations of target compounds in river water reported from western countries and this study

nd; not detected

\begin{tabular}{|c|c|c|c|c|c|c|c|c|c|c|c|c|c|c|c|c|c|c|c|c|}
\hline & \multicolumn{2}{|c|}{ Japan (this study) } & \multicolumn{3}{|c|}{ Germany } & \multicolumn{3}{|c|}{ Austria } & \multicolumn{3}{|c|}{ Swizerland } & \multicolumn{3}{|c|}{ Ilaty } & \multicolumn{3}{|c|}{ U.S.A. } & \multicolumn{3}{|c|}{ canada } \\
\hline & $\begin{array}{c}\text { conc. } \\
\text { min-nax }\end{array}$ & $\begin{array}{c}\text { No. of } \\
\text { detection }\end{array}$ & $\begin{array}{c}\text { conc. } \\
\text { nish-nlax } \\
\text { or } \quad \max \\
\end{array}$ & $\begin{array}{c}\text { No. of } \\
\text { detection }\end{array}$ & ref. & $\begin{array}{l}\text { conc. } \\
\operatorname{min-max}\end{array}$ & $\begin{array}{l}\text { No. of } \\
\text { detection }\end{array}$ & ref. & $\begin{array}{l}\text { contc, } \\
\text { min-max }\end{array}$ & $\begin{array}{l}\text { No. of } \\
\text { detection }\end{array}$ & ref. & $\begin{array}{l}\text { conc. } \\
\min +\max \end{array}$ & $\begin{array}{l}\text { No. of } \\
\text { detection }\end{array}$ & ref. & $\begin{array}{l}\text { conc. } \\
\text { mill-max or } \\
\text { median }\end{array}$ & $\begin{array}{c}\text { No. of } \\
\text { detection }\end{array}$ & ref. & $\begin{array}{c}\text { conc. } \\
\text { min-max }\end{array}$ & $\begin{array}{l}\text { No. of } \\
\text { detection }\end{array}$ & ref. \\
\hline carbanazepine & 1.5 .50 .0 & $24 / 24$ & $<50-1100$ & $24 / 26$ & (4) & $23-133.1$ & $4 / 4$ & (23) & $30-250$ & $17 / 17$ & (24) & & & & 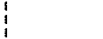 & & & $n \mathrm{~d} \sim 650$ & 811 & (21) \\
\hline propranolol & $<0.2-9.3$ & $20 / 24$ & $<25.590$ & $26 / 45$ & (4) & & & & & & & & & & & & & & & \\
\hline sulfadimethoxine & $<0.03-16.2$ & $20 / 24$ & & & & & & & & & & & & & $\begin{array}{c}<100-15000 \\
n d-60\end{array}$ & $\begin{array}{l}5 / 8 \\
1 / 84\end{array}$ & $\begin{array}{l}\text { (26) } \\
\text { (5) }\end{array}$ & & & \\
\hline sulfametoxazol & $<0.2-413.2$ & $23 / 24$ & $\begin{array}{c}30-85 \\
480\end{array}$ & $\begin{array}{c}4 / 5 \\
26 / 52\end{array}$ & $\begin{array}{l}(22) \\
(18)\end{array}$ & & & & & & & & & & $\begin{array}{l}<100-1020 \\
\pi d-520\end{array}$ & $\begin{array}{c}1 / 8 \\
16 / 84\end{array}$ & $\begin{array}{l}(26) \\
\text { (5) }\end{array}$ & & & \\
\hline tylosin & $<0.01-3.2$ & $12 / 24$ & & & & & & & & & & $<0.3-2.8$ & $3 / 8$ & (25) & $n d-280$ & $14 / 104$ & (5) & & & \\
\hline letracycline & $<3.4-94.8$ & $1 / 24$ & $<50$ & & (16) & & & & & & & & & & $<1004-110$ & $1 / 5$ & (26) & & & \\
\hline & & & $<50$ & $0 / 14$ & (18) & & & & & & & & & & $n d-110$ & $1 / 84$ & (5) & & & \\
\hline oxytetracycline & $<1.5-88.8$ & $8 / 24$ & $<0$ & & (16) & & & & & & & $<0.3-19.2$ & $4 / 8$ & (25) & $<100-1340$ & $5 / 8$ & (26) & & & \\
\hline & & & $<50$ & $0 / 14$ & (18) & & & & & & & & & & $\pi d-340$ & $1 / 84$ & (5) & & & \\
\hline chlortetracycline & $<7.9-13.4$ & $1 / 24$ & $<50$ & & (16) & & & & & & & & & & $<100-150$ & $1 / 8$ & (26) & & & \\
\hline & & & & & & & & & & & & & & & $\operatorname{nd}-690$ & $2 / 84$ & (5) & & & \\
\hline
\end{tabular}

\section{4.屯とめ}

本研究において, 河川水, 下水処理場放流水における医 薬品の分析方法を確立し，日本の河川における医萝品の污 染状況を明らかにした。また，標潐添加法を用いて LC/MS/MSの夾雑物によるイオン化影響を補正すること ができた。海外の環境中の医媇品分析方法はほとんどが緦 対检量線法を用いており, 本研究の分析方法はより定量的 に計算できる方法である。

人用医蒋品であるカルバマゼピンとプロプラノロール は，下水処理場放流水中濃度が河川水よりも高く，人用医 薬品は下水処理場を通じて河川への排出されていること が明らかとなった。しかし，下水道が普及していない地域 を流域に含さ金目川においてもこれらの物質が検出され， 個々の家庭の浄化槽からの医薬品の排出が考えられので, 下水処理場のみが人用医萝品の排出源之考元ることは適 当でない。

多摩川・鶴見川で検出されたサルファ剂は人に使用され たものである可能性が大きいが, 金目川の農業排水の多く 含む採水地点からも多摩川・鶴見川で检出された濃度と比 較して約2〜5倍高い濃度で検出され，金目川で检出された サルファ剂は畜産由来のものであることが推測された。

畜産で多く使用される抗生物質も金目川では高い頻度 で検出されたことから，都市河川である多摩川・鶴見川之 農業排水を多く含む金目川では医葲品の検出傾向が違う ことが明らかとなった。水量の少ない河川において，音産 排水の放流時間に一眭的に抗生物質が高濃度となる可能 性が示㳂され，今後水生生物への影響を調查する必要があ 万。

今回は全てグラブサンプリングであり,サンプリング回 数も少なかったことから，平均的な様子を把握できたとは 言えず、今後は季節变動などを見るために年間を通じて採 水し, デ一夕を取集していく必要がある。
謝辞

本研究は文部科学省21世紀COEプログラム「生物・生態 環境りスクマネジメント」の支援を受け，分析の一部は 横浜国立大学機器分析評価センターの設備を利用して行 わ扎まし。また, 財団法人クリ夕水・環境科学振興財団 から研究助成金を承りました。ここに記して感謝の意を表 します。

（原稿受付 2004年 6月 2日）

（原稿受理 2004年8月12日）

\section{参考文献}

1) Richardson, M. L. and Bowron, J. M. (1985) The fate of phatmaceutical chemicals in the aquatic environment, The Journal of Pharmacy and Pharmacology, 37, 1-12.

2) Halling-Sørensen, B., Nielsen, S., Lanzky, P. F., Ingerslev, F., Lützhøft, H.C. and Jørgensen, S. E. (1998) Occurrence, fate and effects of pharmaceutical substances in the environment--a review, Chemosphere, 36(2), 357-93.

3) Jorgensen, S. E. and Halling-Sørensen, B. (2000) Drugs in the environment, Chemosphere, 40, 691-699.

4) Terns, T. A., (1998) Occurrence of drugs in German sewage treatment plants and rivers, Water Research, 32, 3245-3260.

5) Kolpin, D. W., Furlong, E. T., Meyer, M. T., E. Thurman E. M., Zaugg, S. D., Barber, L. B., and Buxton, H. T. (2002) Pharmaceuticals, hormones, and other organic wastewater contaminants in U.S. streams, 1999-2000: A national reconnaissance, Environmental Science and Techology, 36, 1202-1211.

6) Holm, J. V., Kirsten Rügge, P., Bjerg, P. L. and Christensen, T. H. (1995) Occurrence and distribution of pharmaceutical organic compounds in the groundwater downgradient of a landfill (Grindsted, Denmark), Environmental Science and Techology, 29, 1415-1420.

7) Kümmerer, K. (2001) Drugs in the environment; emission of drugs, diag- 
nostic aids and disinfectants into wastewater by hospitals in relation to other sources - a review, Chemosphere, 45, 957-969.

8) Jones, O. A., Voulvoulis, N. and Lester, J. N. (2002) Aquatic environmental assessment of the top 25 English prescription pharmaceuticals, Waet$r$ Research, 36(20), 5013-5022.

9) Straub, J. O. (2002) Environmental risk assessment for new human pharmaceuticals in the European Union according to the draft guidel ine-discussion paper of January 2001, Toxicology Letter, 131, 137-143.

10) 薬事工業生産動態統計年竍 平成14年 2003 厚生労働省 薬 事協会.

11）動物用医薬品，医薬部外品及び医潦用具生産（翰入）販売高年報

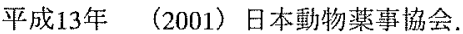

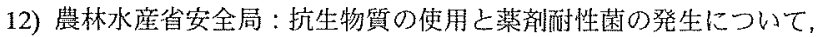
http://www.maff.go.jo/syoku_anzen/20031110/giji.pdf

13) 京浜河川事務所: 多摩川, http://www.keihin.ktr.mlit.go.jp/tama/index. htm

14) 京浜河川事務所：鳰見川I, http://www.keihin.ktr.mlit.go.jp/tsurumi/in dex.him

15) 平堟士木管理事務所: 平塚市が管理する河川I, http://www.pref.kana gawa.jp/osirase/07/1912/hirado/kanrikasen/kawalist.htm

16) Hirsch, R., Ternes, T. A., Haberer, K., Mehlich, A., Ballwanz, F. and Kratz, K. L. (1998) Determination of antibiotics in different water compartments via liquid chromatography-electrospray tandem mass spectrometry, Journal of chromatograplyy $A, 815,213-223$.

17) Hamscher, G., Sczesny, S., Höper, H. and Nau, H. (2002) Determination of persistent tetracycline residues in soil fertilized with liquid manure by high-performance liquid chromatography with electrospray ionization tandem mass spectrometry, Analytical Chemistry, 74, 1509-1518.

18) Hirsch, R., Ternes, T. A., Haberer, K. and Kratz K. L. (1999) Occurrence of antibiotics in the aquatic environment, The Science of The Total En- viromment, 225, 109-118.

19) Andreozzi, R., Raffaele, M. and Nicklas, P. (2003) Pharmaceuticals in STP effluents and their solar photodegradation in aquatic environment, Chemosphere, 50, 1319-1330.

20) Huggett, D. B., Khan, I. A., Foran, C. M. and Schlenk, D. (2003) Determination of beta-adrenergic receptor blocking pharmaceuticals in united states wastewater effluent, Environmental Pollution, 121(2), 199-205.

21) Temes, T. A. and Struger, J. (2002) Prescription and non-prescription drugs in the Canadian aquatic environment, EC/HC Workshop, draft data.

22) Hartig, C., Storm, T. and Jekel, M. (1999) Detection and identification of sulphonamide drugs in municipal wastewater by liquid chromatography coupled with electrospray ionization tandem mass spectrometry, Journal of chromatography A, 854, 163-173.

23) Ahrer, W., Scherwenk, E. and Buchberger, W. (2001) Determination of drug residues in water by the combination of liquid chromatography or capillary electrophoresis with electrospray mass spectrometry, Joumal of chromatography $A, 910,69-78$.

24) Öllers, S., Singer, H. P., Fässler, P. and Müller, S. R. (2001) Simultaneous quantification of neutral and acidic pharmaceuticals and pesticides at the low-ng/l level in surface and waste water, Journal of Chromatography $A, 911,225-234$.

25) Calanari, D., Zuccato, E., Castiglioni, S., Bagnati, R. and Fanelii, R. (2003) Strategic survey of therapeutic drugs in the rivers Po and Lambro in northern Italy, Environmental Science and Technology, 37, 1241-1248.

26) Lindsey, M. E., Meye, T. M. and Thurman, E. M. (2001) Analysis of trace levels of sulfonamide and tetracycline antimicrobials in groundwater and surface water using solid-phase extraction and liquid chromatography/mass spectrometry, Analytical Chemistry, 73, 4640-4646. 